DEPARTMENT OF THE INTERIOR

U.S. GEOLOGICAL SURVEY

LATE TERTIARY AND QUATERNARY GEOLOGY OF THE TECOPA BASIN, SOUTHEASTERN CALIFORNIA

By John W. Hillhouse

MISCELLANEOUS INVESTIGATIONS SERIES

Published by the U.S. Geological Survey, 1987

G 


\title{
LATE TERTIARY AND QUATERNARY GEOLOGY OF THE TECOPA BASIN, SOUTHEASTERN CALIFORNIA
}

\author{
By \\ John W. Hillhouse
}

\begin{abstract}
Stratigraphic units in the Tecopa basin, located in southeastern California, provide a framework for interpreting Quaternary climatic change and tectonism along the present Amargosa River. During the late Pliocene and early Pleistocene, a climate that was appreciably wetter than today's sustained a moderately deep lake in the Tecopa basin. Deposits associated with Lake Tecopa consist of lacustrine mudstone, conglomerate, volcanic ash, and shoreline accumulations of tufa. Age control within the lake deposits is provided by air-fall tephra that are correlated with two ash falls from the Yellowstone caldera, the Lava Creek (0.62 Ma) and Huckleberry Ridge (2.02 $\mathrm{Ma}$ ) Tuffs, and one from the Long Valley caldera, the Bishop Tuff (0.73 Ma). Paleomagnetic determinations from deposits in the Tecopa basin are consistent with the ages of the ashes. Extrapolations of ages using average sedimentation rates suggest that the beds of Lake Tecopa, which accumulated to a minimum thickness of $72 \mathrm{~m}$, are 0.5 to 3 m.y. old. In the central part of the basin, volcanic glass has been replaced by authigenic silicate minerals that formed in porewater of extremely high salinity and alkalinity. Therefore, Lake Tecopa occupied a closed basin during the latter part, if not all, of its 2.5-million-year history.
\end{abstract}

Sometime after 0.5 m.y. ago, the lake developed an outlet across Tertiary fanglomerates of the China Ranch Beds leading to the development of a deep canyon at the south end of the basin and establishing a hydrologic link between the northern Amargosa basins and Death Valley. After a period of rapid erosion, the remaining lake beds were covered by alluvial fans that coalesced to form a pediment in the central part of the basin. Remnants of these fans are capped by desert soil horizons composed of: (1) a clay-rich B-Horizon, (2) a thin bed of vesicular tan silt (A-horizon), and (3) densely packed pavement with welldeveloped desert varnish. The B-horizon of one such fan yielded an age of $160,000 \pm 18,000$ years by the uraniumtrend method. The Tecopa basin bears no evidence of Lahontan-age lake deposits. Holocene deposits consist of unconsolidated sand and gravel in the Amargosa River bed and its deeply incised tributaries, a small playa near Tecopa, alluvial fans without pavements, and small sand dunes. The pavement-capped fan remnants and the Holocene deposits are not faulted or tilted significantly, although basins to the west, such as Death Valley, were tectonically active during the Quaternary. Subsidence of the western basins strongly influenced late Quatemary rates of deposition and erosion in the Tecopa basin.

\section{INTRODUCTION \\ SCOPE OF THE INVESTIGATION}

The objectives of this study were to establish the distribution, age, and structure of Quaternary deposits in the Tecopa basin. This information provides a basis for interpreting past episodes of faulting and climatic change in the Amargosa River drainage system. The Tecopa basin is ideal for studies of Quaternary history because erosion has clearly exposed the stratigraphy, and the deposits of Pleistocene Lake Tecopa have proven to be datable. Volcanic ash beds within the lake deposits have been chemically correlated with isotopically dated volcanic sources in the Yellowstone (Wyoming) and Long Valley (California) calderas (Izett, 1981; Sarna-Wojc:cki and others, 1984). In addition, the continuous sedimentary record of the lake beds provides an opportunity for paleomagnetic correlations. With age control offered by the volcanic ashes, magnetozones in the lake deposits can be correlated with the geomagnetic polarity time scale (Mankinen and Dalrymple, 1979).

Proterozoic and Cambrian sedimentary rocks and Tertiary volcanic rocks of the region were given only a cursory examination as far as establishing source terranes for the Quaternary alluvium. No efforts were made to describe stratigraphy, faults, or other structures in the bedrock of the ranges. Information on the bedrock geology of the Tecopa area is found in reports by Hazzard (1937), Mason (1948), Noble and Wright (1954), and Troxel and Wright (1976).

In constructing the geologic map, contacts between Quaternary units that have developed distinctive geomorphologies were marked on aerial photographs (scale 1:47,200) and then transferred to the topographic base (scale 1:48,000) with a stereographic plotter. These units were checked and described during fieldwork in the winter of 1981. The lake deposits and outcrops of the thicker volcanic ashes were mapped in the field on aerial photographs and contacts were then plotted on the topographic base. Several stratigraphic sections were measured in the lake beds.

Paleomagnetic investigations of the lake deposits, made primarily in 1971-74, and supplemented in 1978, involved the collection of oriented sediment cubes. Sampling was limited to steep-walled outcrops to obtain relatively unweathered material. The samples were given a standard treatment in alternating magnetic fields to remove unstable magnetic components and to reveal the original depositional remanent magnetization (McElhinny, 1973). Magnetozones were established from several equivalent 
stratigraphic sections that were closely correlated by volcanic ash beds.

\section{PHYSIOGRAPHY}

The Tecopa basin is in the southeastern part of Inyo County, California, about $30 \mathrm{~km}$ east of the south end of Death Valley. In this report "Tecopa basin" refers to the part of the Amargosa River drainage that lies chiefly between the towns of Shoshone and Tecopa and includes the southeast end of Greenwater Valley and the southern half of Chicago Valley (fig. 1).

The Tecopa basin can be considered a southern extension of the Amargosa Desert, which generally lies between Eagle Mountain on the south $(25 \mathrm{~km}$ north of Shoshone) and the Bullfrog Hills on the north $(120 \mathrm{~km}$ northwest of Shoshone). The areal extent of the Tecopa basin is approximately $500 \mathrm{~km}^{2}$. The region is characterized by arid sparsely vegetated valleys and bare rugged mountain ranges. A dominant feature of the Tecopa area is the Amargosa River, which is dry except during infrequent thunderstorms or near permanent springs at Shoshone and Tecopa. North of Shoshone as far as Eagle Mountain, the river bed follows a nearly linear channel, which has cut approximately $25 \mathrm{~m}$ into the surrounding alluvial piedmont. South of Shoshone, the river bed broadens into a braided plain surrounded by badlands of low rounded hills, mesas, and deeply dissected alluvial fans. A small playa forms the floor of the depression near Tecopa. South of Tecopa, the river descends through a narrow canyon, of which steep walls are locally more than $100 \mathrm{~m}$ high. The basin is flanked by banded brightly colored rocks of the Resting Spring Range on the east and the Dublin Hills on the west (fig. 1). The Sperry Hills, which are bisected by the canyon of the Amargosa River, make up the southern margin of the Tecopa basin. Mean annual precipitation ranges from $7 \mathrm{~cm}$ in the valleys ( $\sim 460 \mathrm{~m}$ elevation) to $15 \mathrm{~cm}$ in the higher parts of the Resting Spring Range ( $\sim 1,000$ m elevation) (Winograd and Thordarson, 1975). PREVIOUS WORK

Sheppard and Gude (1968) reviewed the early geologic studies of the Tecopa area, most of which concerned exploration for nitrates, borates, and pumicite. General geology of the Tecopa basin is summarized by Mason (1948) and Noble and Wright (1954). Detailed geologic maps, at 1:24,000 scale, were published for the southeast quarter of the Tecopa quadrangle (Wright, 1974) and the northeast quarter of the Shoshone quadrangle (Chesterman, 1973). Tertiary volcanic rocks in the Dublin Hills were studied by Haefner (1976). In general, emphasis of previous work was on the bedrock geology, so the Quaternary deposits received only cursory examinations.

Pleistocene Lake Tecopa, which was named and described in a brief article by Blackwelder (1936), has been the subject of several geochemical and mineralogical studies. Sheppard and Gude (1968) described the stratigraphy and approximate distribution of the lake beds in a study that focused on the formation of authigenic silicate minerals, particularly zeolites, within volcanic ashes of the basin. Starkey and Blackmon (1979) investigated the distribution and origin of clay minerals in the lacustrine deposits.

\section{STRATIGRAPHY}

ARCHEAN, PROTEROZOIC, AND CAMBRIAN ROCKS

The oldest rocks within the study area are granitic gneiss at the southwest end of the Nopah Range and in the Ibex Hills. The gneiss contains metadiorite dikes to which Chesterman (1973) assigned an Archean age. Exposed in the rugged banded cliffs of the eastern Dublin Hills and the Resting Spring Range is a nearly complete succession of uppermost Proterozoic to Middle Cambrian marine sedimentary rocks. The sequence consists of the, ascending, Noonday Dolomite (Proterozoic), Johnnie Formation (Proterozoic), Stirling Quartzite (Proterozoic), Wood Canyon Formation (Proterozoic and Lower Cambrian), Zabriskie Quartzite (Lower Cambrian), Carrara Formation (Lower and Middle Cambrian), and the Bonanza King Formation (Middle and Upper Cambrian).

\section{TERTIARY VOLCANIC ROCKS}

Volcanic flows and tuffs, predominantly of rhyolitic composition, are exposed in the western Dublin Hills and the Resting Spring Range. Haefner (1976) applied the name "Shoshone Volcanics" to the pyroclastic rocks of the Dublin Hills. The Shoshone Volcanics, which consist of pumice lapilli tuff and welded tuff, are part of a large Tertiary volcanic terrane exposed throughout the Greenwater Range and the Black Mountains. The welded units are crystal poor in the Dublin Hills, but elsewhere they contain abundant phenocrysts of plagioclase, hornblende, and biotite. The unwelded units consist of blocks of andesite and rhyolite, rare clasts of dolomite and quartzite, and a devitrified pumice lapilli matrix. Haefner (1976) considered the Shoshone Volcanics equivalent to part of the "older volcanics" that underlie the Greenwater Volcanics of the Funeral Peak quadrangle (Drewes, 1963). Potassium-argon ages, principally from biotite, range from 6.32 to $8.02 \mathrm{Ma}$ for the "older volcanics" and range from 5.32 to $5.47 \mathrm{Ma}$ for the Greenwater Volcanics (Fleck, 1970). Volcanic flows at the northwest end of the Dublin Hills have yielded $\mathrm{K}$-Ar ages of $7.9 \mathrm{Ma}$ (plagioclase) and $8.7 \mathrm{Ma}$ (glass) according to E. W. Hildreth and R. E. Drake (oral commun., November, 1982).

Pyroclastic rocks of Tertiary age are exposed along the east flank of the Resting Spring Range and make up the prominent butte that is $4 \mathrm{~km}$ northeast of Shoshone. An excellent example of these pyroclastic rocks is exposed in the road cut where California Highway 178 crosses the Resting Spring Range (Troxel and Heydari, 1982). The cut exposes devitrified pumice tuff, welded tuff, and vesicular vitrophyre, dated by $\mathrm{K}-\mathrm{Ar}$ methods at $9.5 \mathrm{Ma}$ (R. E. Drake, oral commun., November, 1982). Although the distribution of volcanic rocks of the Resting Spring Range is shown on geologic maps by Mason (1948) and Noble and Wright (1954), detailed descriptions, isotopic ages, or the relation of these volcanic rocks to similar units farther west have not been published.

\section{TERTIARY BASALT}

Isolated remnants of basalt are exposed $1 \mathrm{~km}$ north of Shoshone and in the vicinity of the southern Dublin Hills. The basalt forms black rounded hills strewn with blocks as much as several meters in diameter. The olivine-rich basalt is fine grained, moderately porphyritic, and highly vesicular. Just north of Shoshone the basalt overlies buff- 

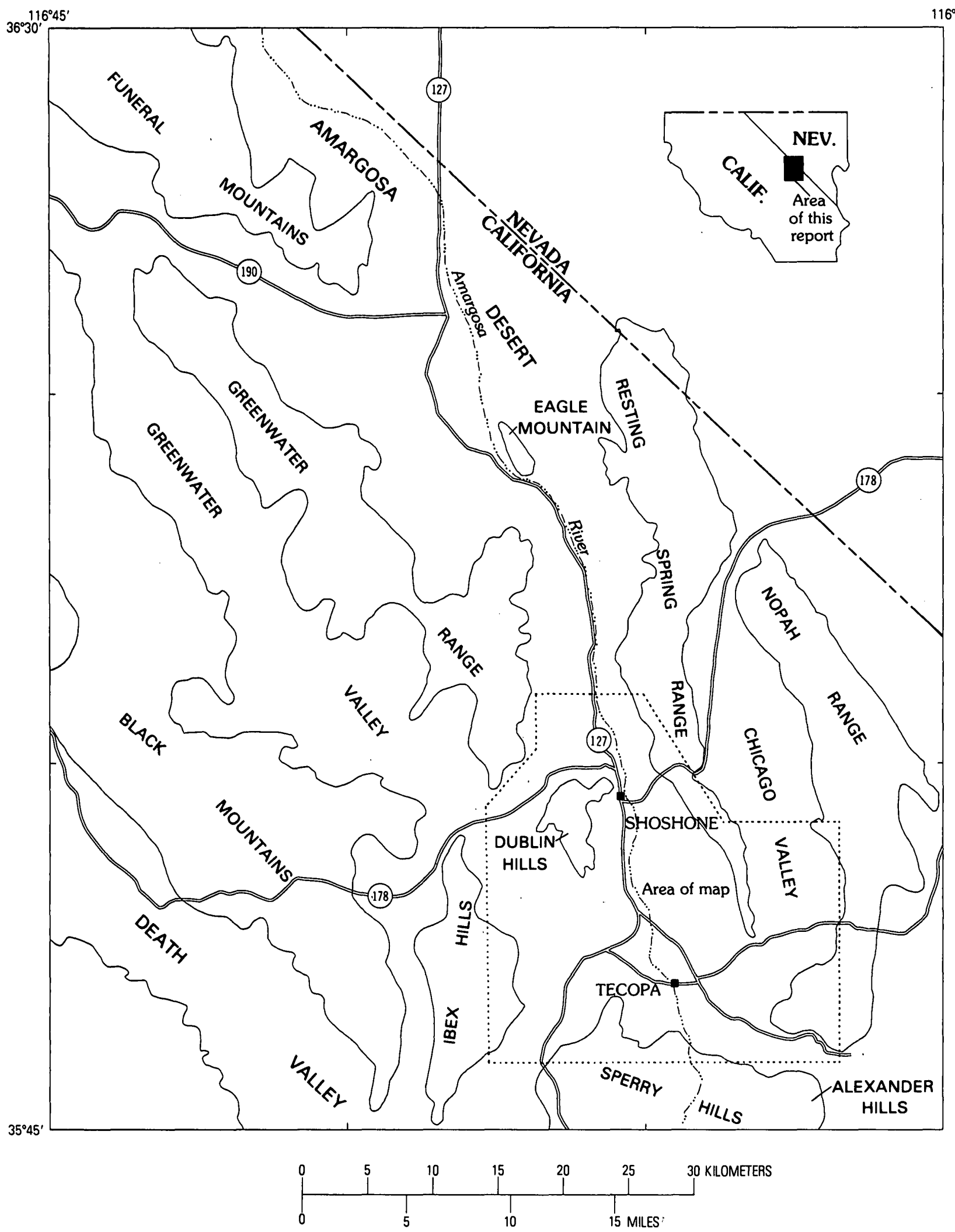

FIGURE 1.-Major geographic features of the Amargosa region. Dotted line indicates boundary of Tecopa basin. 
colored tuff that consists of rounded pumice cobbles, volcanic rock fragments, and pumiceous matrix.

Chesterman (1973) assigned a Quaternary age to the basalt and stated that the unit overlies deformed lacustrine deposits of Pleistocene Lake Tecopa. However, tuffaceous lake beds were found on top of the eroded basaltic mound on the east side of the Amargosa River, $1 \mathrm{~km}$ north of Shoshone. Inasmuch as the oldest deposits of Lake Tecopa are late Pliocene (see section on "Age of Lake Tecopa"), the basalt is presumably of Tertiary age. In the Dublin Hills, the basalt and related tuff directly overlie Paleozoic carbonate rocks, so the maximum age of the volcanic unit is poorly constrained. Because the stratigraphic relation of the basalt to the Shoshone Volcanics is not demonstrated and because basalt eruptions occurred sporadically in the Amargosa region throughout the late Tertiary and Quaternary, only tentative conclusions can be made concerning the timing of basaltic volcanism at Shoshone.

The basalt may be related to volcanism that produced part of the Funeral Formation (Drewes, 1963; Denny and Drewes, 1965), which includes a large area of basalt flows in the eastern Greenwater Range. In fact, Noble and Wright (1954) described the Shoshone basalt as part of their Funeral Fanglomerate of Pliocene and Pleistocene(?) age (renamed the Funeral Formation by Drewes, 1963) in their generalized geologic map of the Death Valley region. If this tentative correlation is correct, then the basalt is younger than $5.4 \mathrm{Ma}$, which is the isotopically determined age of the Greenwater Volcanics that underlie the Funeral Formation in the Funeral Peak quadrangle. A basalt flow in the type section of the Funeral Formation near Ryan yielded a whole-rock $\mathrm{K}-\mathrm{Ar}$ age of $4.03 \pm 0.12 \mathrm{Ma}$ (McAllister, 1973).

\section{TERTIARY CHINA RANCH BEDS}

Debris flows, fanglomerate, pumice beds, and gypsiferous mudstone in the Sperry Hills compose the China Ranch Beds, which are well exposed in the Amargosa canyon south of Tecopa. Mason (1948) originally applied the name to the light-colored mudstones and gypsiferous beds that crop out in the vicinity of China Ranch. However, Wright (1974) redefined the unit to include the coarse fanglomerate that interfingers with the gypsiferous mudstones. The fanglomerate lithology of the China Ranch Beds is prevalent in the Alexander Hills (fig. 1) and in the western part of the Sperry Hills.

Exposures of the fanglomerate south of Tecopa Pass, consist of bodies of monolithologic conglomerate interbedded with heterogeneous material (Wright, 1974). The monolithologic conglomerates, which are present as lenses as long $300 \mathrm{~m}$, are slump blocks of bedrock derived from the nearby ranges. West of the Amargosa River, the fanglomerate is a heterogeneous unit of gneiss, granite, and dolomite boulders. Quartzite, metasedimentary rocks, and volcanic rocks are common but less abundant. The subrounded boulders, which are 1 to $5 \mathrm{~m}$ in diameter, are set in a sand and gravel matrix of similar lithology. In the cliffs of the Amargosa canyon, where at least $100 \mathrm{~m}$ of the fanglomerate is exposed, the poor sorting and crude bedding of the unit is readily apparent. The unit originated as debris flows and stream deposits derived from the ancestral Sperry Hills, which consisted primarily of Tertiary(?) granite and Archean gneiss. The ancient fan has been modified by extensive faulting.

Lenses of white pumice fill ancient channels within the fanglomerate. The lenses, as much as $5 \mathrm{~m}$ thick, consist of pumice clasts in a white lapilli matrix. The clasts are well rounded and are from 1 to $5 \mathrm{~cm}$ in diameter. Pumice lenses are generally no more than a few tens of meters wide, although one extensive pumice bed is exposed in the northern Amargosa canyon, $3 \mathrm{~km}$ south of Tecopa. This 5 $\mathrm{m}$-thick bed is a complex of pumice pebbles and cobbles interbedded with pumice lapilli and coarse arkosic sandstone. The clasts are well rounded and present in laminar graded (upward fining) beds as much as $20 \mathrm{~cm}$ thick. Pumice cobbles are rich in sanidine phenocrysts.

The pumice bed is traceable southward from the fanglomerate into gypsiferous mudstones. The crudely bedded fan deposit is finer grained to the south and eventually interfingers with buff and pale-pink mudstones, which are well bedded and contain abundant gypsum. Total exposed thickness of the mudstone is approximately $400 \mathrm{~m}$. The gypsum beds suggest a shallow lacustrine environment or playa, where evaporation was dominant. The mudstones are extensively faulted and deformed into tight plunging folds.

The China Ranch Beds overlie and incorporate material from the Cambrian and older bedrock, Tertiary(?) granite from the Sperry Hills, and the Tertiary volcanic rocks. The beds underlie the deposits of Lake Tecopa and form the southern margin of the lake basin. In a few places, a slight angular unconformity is indicated where lake-age gravels filled depressions in the eroded and tilted China Ranch Beds. Noble and Wright (1954) and Wright (1974) assigned a Pliocene and Pleistocene(?) age to the China Ranch Beds on the basis of stratigraphic relations. Because the beds unconformably underlie lake beds of earliest Pleistocene age, the China Ranch Beds are considered to be wholly Tertiary.

In many ways, the China Ranch Beds are similar to the Funeral Formation of the Death Valley region. For example, the Funeral Formation consists of coarse fan deposits with large slump blocks, playas, and pumiceous tuff (Drewes, 1963), as are found in the vicinity of China Ranch. The presence of huge blocks and megabreccias within the fanglomerates suggests that uplift and accelerated erosion were affecting the highlands throughout the region. This tectonic activity, which probably occurred during the Pliocene, was accompanied by local volcanic activity.

QUATERNARY LAKE BEDS, CONGLOMERATE, AND TUFA

The deposits of Lake Tecopa (fig. 2a) are divided into three informal units that are mapped separately: (1) lacustrine mudstone, (2) conglomerate, and (3) tufa. Deposits of Lake Tecopa occupy the low region between Shoshone and Tecopa and the southern end of Chicago Valley. The maximum areal extent of the lake was approximately $250 \mathrm{~km}^{2}$. The southern margin of the lake was originally buttressed by fanglomerate of the China Ranch Beds, now breached by the Amargosa River. 


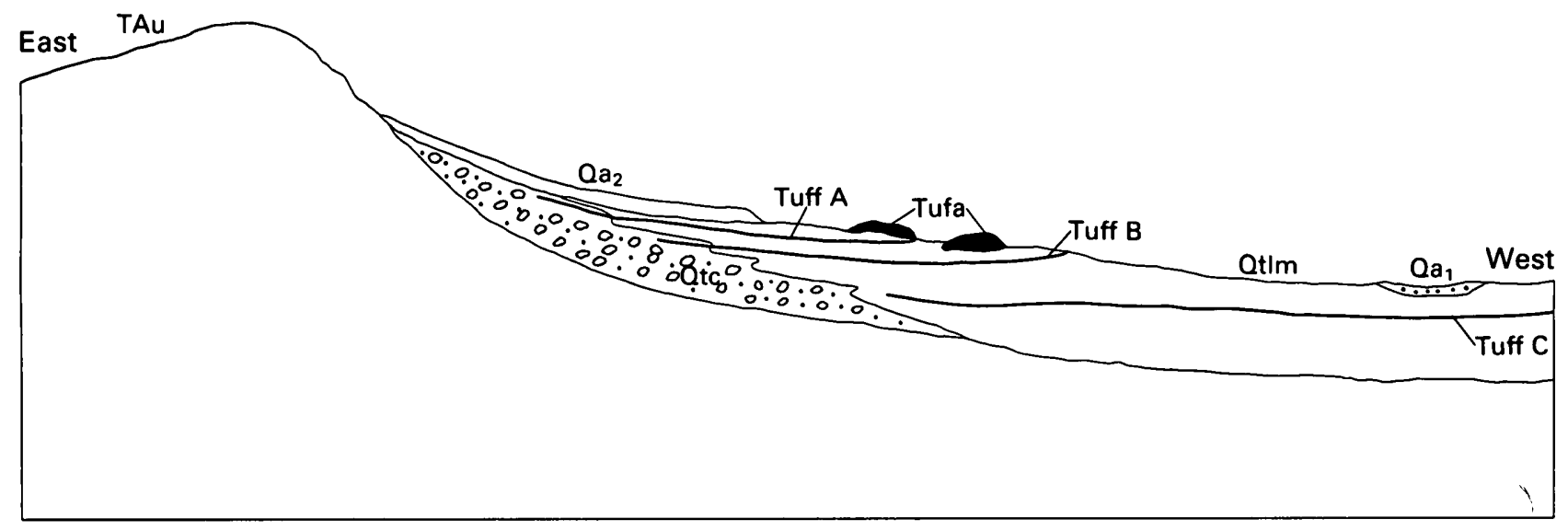

FIGURE 2a.-Schematic geologic cross section of the deposits of Lake Tecopa: lacustrine mudstone unit (Qtim) including tuffs A, B, and C of Sheppard and Gude (1968), conglomerate unit (Qtc), and tufa. Also shown are basement rocks (TAu) composed of Archean gneiss, Proterozoic and Paleozoic sedimentary rocks, Tertiary volcanic rocks, as well as older Quaternary alluvium $\left(\mathrm{Qa}_{2}\right)$, and Holocene alluvium $\left(\mathrm{Qa}_{1}\right)$.

Lacustrine mudstone

A cumulative thickness of $72 \mathrm{~m}$ of mudstone, claystone, and volcanic ash is exposed (fig. 2b), although the level of erosion has not reached the base of the lake deposits in the central part of the basin. Stratigraphic section 1 was measured $1.5 \mathrm{~km}$ northeast of Shoshone, section 2, $2 \mathrm{~km}$ east of Shoshone, and section 3 was measured near the southern end of the Dublin Hills. The sediments have pastel colors ranging from buff and pink near the lake margins to green and brown in the central basin. Badland topography developed on the lacustrine mudstone unit generally consists of low rounded mounds with knobby surfaces resembling popcorn, caused by the wetting and drying of expandable clay minerals. Near the lake margins, the deeply dissected lake beds form vertical walls. Several thick volcanic ash beds form orange or white resistant ledges in the walls of the arroyos.

The dominant lithology is mudstone that consists of clay, silt, and minor amounts of sand. The mudstone contains calcite, clay minerals, mineral and rock fragments, and gypsum fills cracks. Authigenic zeolites and potassium feldspar are also present in the mudstone. Claystone, which breaks with a brittle conchoidal fracture, is interbedded with mudstone and is most common in the middle part of the lake beds. The predominant detrital clay minerals are illite, lithium-rich saponite, and montmorillonite, (Starkey and Blackmon, 1979). Grain sizes of the sedimentary rocks become coarser toward the main inlet north of Shoshone and toward the tributaries of Greenwater and Chicago Valleys. Lenses of sandstone and subrounded pebbles mark the channels of ancient streams at the inlets. The subangular sand grains consist of quartz, feldspar, biotite, and silicic volcanic-rock fragments. The dominant lithologies of the pebbles are basalt and silicic volcanic rocks.

The mudstones are generally well bedded and nearly flat lying, although the beds dip approximately $1^{\circ}$ toward the center of the basin. Minor warps, slumps, and depressions were noted in a few limited areas (see fig. 5, Sheppard and Gude, 1968). The claystone beds tend to be massive, especially in the central part of the basin.

For the most part, the lake sediments are moderately indurated, but tend to disaggregate easily during wetting. However, localized concentrations of calcite produce resistant ledges and beds especially near Shoshone, where spring water and the Amargosa River entered the lake, and also near the Greenwater fan. Sediments along the lake perimeter tend to be richer in $\mathrm{CaCO}_{3}$ than the sediments of the central basin. Sandstone beds, commonly cemented by carbonate, form nodules and flagstones as much as 50 $\mathrm{cm}$ wide and 5 to $10 \mathrm{~cm}$ thick. The eroded surface of the lake beds is littered with a lag concentration of carbonate flagstones.

Several volcanic ash beds, ranging in thickness from 1 $\mathrm{cm}$ to $4 \mathrm{~m}$, are present in the lake deposits. Of the 12 ashes that are recognized, three form thick beds that are mappable throughout the basin; whereas, the thinner ashes are discontinuous. Sheppard and Gude (1968) provided detailed descriptions of the three thick ashes, and their nomenclature has been followed in referring to the ashes as tuffs $A, B$, and $C$ (from youngest to oldest).

In general, the fresh ashes are white or pale gray and extremely friable. They are composed of rhyolitic vitreous shards and minor amounts of crystal and rock fragments. The basal contacts of the ashes are sharp, suggesting direct air fall into the basin, and the upper contacts are gradational with the overlying mudstones. In many places, the upper parts of the thick ashes have multiple fine beds, ripple marks, grading, and small-scale crossbeds indicative of reworking by water currents. Locally, fresh ash is cemented by $\mathrm{CaCO}_{3}$ to form resistant ledges.

Except near the northern lake margin, where fresh ash predominates, the glass shards are generally altered to zeolites, potassium feldspar, and searlesite. As described by Sheppard and Gude (1968), the authigenesis of the tuffs follows an areal zonation with fresh glass at the outer perimeter, giving way to zeolite (phillipsite, clinoptilolite, and erionite) in the intermediate zone, and finally potassium feldspar and searlesite at the center of the basin. 


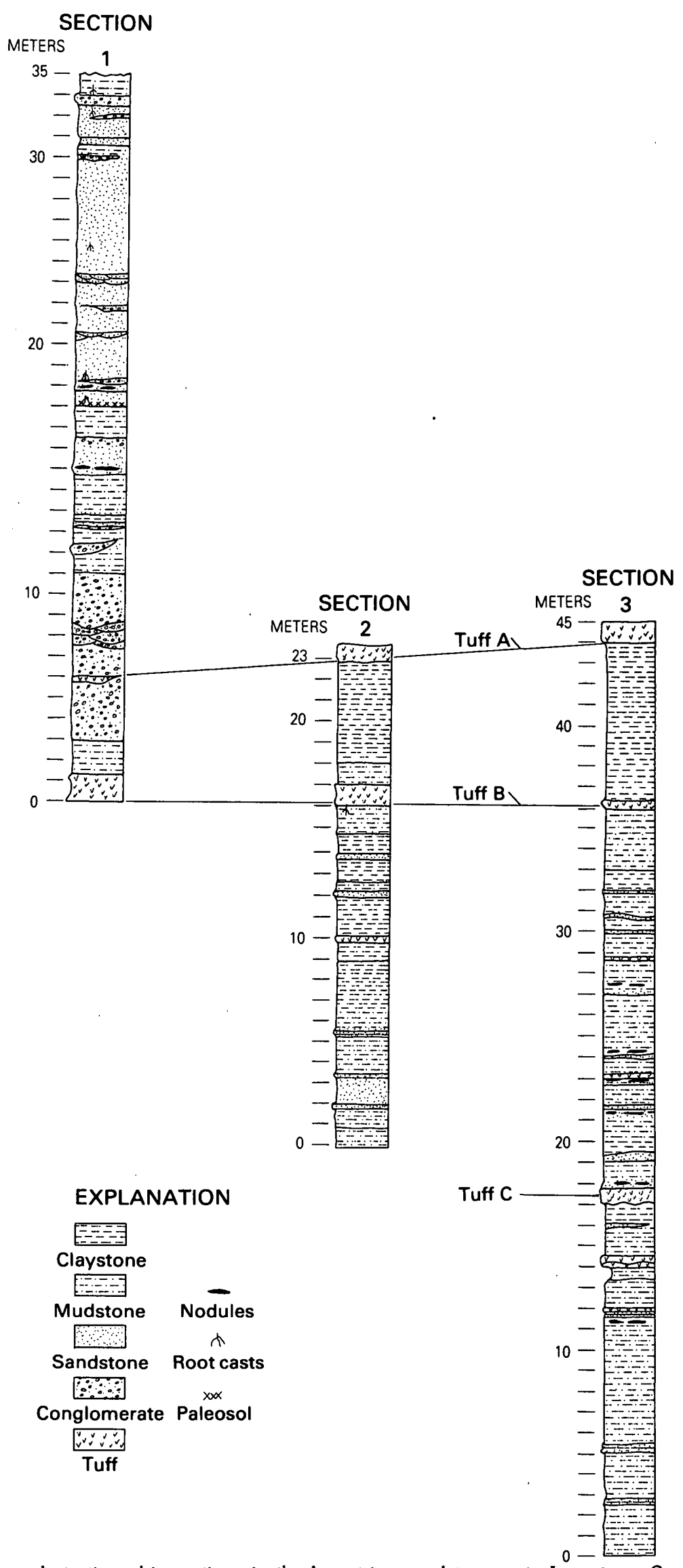

FIGURE $2 b$. - Measured stratigraphic sections in the lacustrine mudstone unit. Locations: Section 1, SE1/4 sec. 19 and SW1/4 sec. 20, T. 22 N., R. 7 E.; Section 2, SE1/4 sec. 29 and NE1/4 sec. 32, T. 22 N., R. 7 E.; Section 3 , NW $1 / 4$ sec. 19, T. 21 N., R. 7 E. 
Altered tuff is punky, porous, has a blocky fracture, and forms yellowish or greenish ledges.

Tuff $\mathrm{C}$-The lowermost thick ash, tuff $\mathrm{C}$, is stratigraphically $17 \mathrm{~m}$ above the deepest exposure of the lake beds. Tuff $\mathrm{C}$ is 10 to $75 \mathrm{~cm}$ thick and is best exposed along the west side of California Highway 127, where the altered tuff forms a resistant ledge containing green nodules of silicified clay. Distinctive features of the tuff are the highly contorted and well-laminated upper part and the deformed base, which is generally warped into a wavelike surface with amplitudes of $50 \mathrm{~cm}$ and wavelengths of several meters. Although the cause of the deformation remains a matter of debate, the wavy base is probably a load feature, but the contorted upper part may be due to turbidity flow. Seismic shaking has been proposed as an alternative cause of the deformation.

Although the glass shards of tuff $\mathrm{C}$ are predominantly altered to potassium feldspar minerals, a small pocket of fresh ash is preserved near the eastern margin of the basin (SW $1 / 4 \mathrm{sec}$. 24, T. $21 \mathrm{~N}$., R. 7 E.). Fresh ash is mainly of platy bubble wall shards and 1-5 percent rock and crystal fragments. Zircon phenocrysts with glass selvages are present. The bed is difficult to trace in the rounded hills of the central basin, because the outcrops have thick mantles of weathered material.

Tuff $B$-Tuff $B$ is approximately $18 \mathrm{~m}$ stratigraphically above the base of tuff $C$. The stratigraphic interval between the two tuffs, which is predominantly claystone, is poorly exposed except at the southwest part of the lake basin. Tuff B is thick $(0.3$ to $3.5 \mathrm{~m})$ and can be traced almost continuously from the Sperry Hills, along California Highway 127 to Shoshone, then along the west flank of the Resting Spring Range to Chicago Valley. The southern exposures of tuff $B$ are mostly associated with deep-water mudstones, whereas elsewhere the tuff is exposed in shallow fluviatile deposits near the ancient shore. The deep-water exposures contain very minor amounts of locally derived rock fragments. In contrast, on the lower part of the Greenwater fan, the tuff has a clean vitreous base beneath layers containing an abundance of local carbonate and volcanic detritus. The thicker accumulations of the ash tend to be massive except near the base where fine laminations are common. Gypsum-filled root casts are abundant throughout the ash bed in the shallow-water depositional environments. Near the southern tip of the Resting Spring Range, tuff B was deposited by direct air fall onto alluvium, as suggested by the presence of abundant fossilized plant stems in the base of the ash. In the channels of the ancestral Amargosa and Chicago Valley tributaries, tuff B was deposited as a complex of channel fillings and tuffaceous sandy beds. Just northeast of Shoshone on the east side of the Amargosa River, the ash is interbedded with mudstone that was deposited on Tertiary basalt.

The freshest examples of tuff B are near Shoshone and along the Resting Spring Range, where the ash stands out as a white band between underlying pink mudstone and overlying green claystone. Fresh ash is mainly composed of distinctive pumice shards (as much as 0.5 $\mathrm{mm}$ ) having spindles of elongate tubular bubbles. Volcanic rock fragments and crystals, mainly biotite and plagioclase, make up 1 to 10 percent of the ash. Resistant ledges of tuff $B$ at the southwest side of the basin contain authigenic zeolites and potassium feldspar as replacement products of the glass shards. Orange ledges of the altered ash have abundant spherulitic phillipsite within the zeolite facies. In the potassium feldspar facies, the tuff is green or brown.

Tuff A-Tuff $\mathrm{A}$, which is 0.5 to $4 \mathrm{~m}$ thick, is exposed around the perimeter of most of the basin, but was not recognized in Chicago Valley. The $4-8 \mathrm{~m}$ interval that separates tuff $B$ from the overlying tuff $A$ generally consists of green brittle claystone. Tuff $A$ is overlain by about 10 $30 \mathrm{~m}$ of lacustrine sandy mudstone and conglomerate; no ashes were found above this tuff. The best exposures of tuff $A$ are in an abandoned pumicite quarry, $1 \mathrm{~km}$ south of Shoshone, where the 4-m-thick bed consists of silver gray vitric tuff with many laminar interbeds several centimeters thick. The tuff contains only minor amounts of locally derived detritus, although there is ample evidence that the upper part of the bed has been reworked by water currents. Well-preserved ripple laminations indicate a south-southeast current direction. In Greenwater Valley, tuff $\mathrm{A}$ is $2 \mathrm{~m}$ thick and overlies siltstone containing abundant root casts. On a nearby isolated outcrop of Cambrian dolomite, the ash was deposited on talus, suggesting deposition by direct airfall. In the Sperry Hills, the $2.5-\mathrm{m}$-thick bed was deposited on gravels which interfinger with the lake beds. In general, the substantial thickness of the tuff provides a continuous exposure, except near the ancestral Amargosa River channel where the ash is mixed with sand and gravel and forms discontinuous lenses. The lenses exhibit chaotic rip up structures, crossbeds, and ripple marks.

Where fresh, tuff $A$ is predominantly composed of platy glass shards approximately $0.1 \mathrm{~mm}$ in diameter. Rock and crystal fragments typically comprise less than 1 percent of the ash. Where the tuff forms resistant ledges, it displays alteration features similar to those of altered tuff $B$.

\section{Conglomerate}

This unit consists of fanglomerate and pebbly fluviatile deposits that interfinger with the lacustrine mudstone unit. The unit generally forms cobble-strewn low rounded hills that develop dendritic outlines in plan view. Typical exposures of the conglomerate unit are seen in the gravelly piedmont that flanks California Highway 127 north of Shoshone, where the unit consists of coalescing alluvial fans at the foot of the surrounding ranges. The fan deposits, which are at least $50 \mathrm{~m}$ thick, consist of sand, gravel, and subangular cobbles composed of dolomite, quartzite, basalt, and silicic volcanic rocks. Pebble and cobble sizes increase from 1 to $8 \mathrm{~cm}$ near the center of the valley to $20 \mathrm{~cm}$ at the foot of the bedrock ranges. Near the present channel of the Amargosa River, the conglomerate consists of rounded pebbles, 1 to $4 \mathrm{~cm}$ in diameter, and sandy channel fillings that were probably deposited by an ancestral river. These fluviatile sediments are interbedded with tuffs $A$ and $B$ and a 1 -m-thick mudstone bed.

Small remnants of the conglomerate unit are exposed at the foot of the Dublin Hills, the Sperry Hills, and the Resting Spring Range. Where a direct association with lake beds cannot be demonstrated, the remnants are 
distinguished from the younger alluvium by a more rounded dendritic morphology, greater induration due to carbonate cementation, and generally steeper depositional slopes near the range fronts. A shallower slope tends to be present in the younger alluvial deposits because the range fronts have been incised more deeply since the conglomerate unit was deposited. This relation is well demonstrated in the Dublin Hills where conglomerate fan remnants stand above younger pediment gravels that have shallower slopes. Although clasts within the conglomerate carry partial rinds of $\mathrm{CaCO}_{3}$, thick zones of pedogenic caliche have not developed.

In the Sperry Hills, the conglomerate unit is a fan deposit that overlies the eroded surface of the China Ranch Beds with a slight angular unconformity. This contact is best exposed in the uppermost $10 \mathrm{~m}$ of the west wall of the Amargosa canyon. Compositionally, the Quaternary conglomerate unit is difficult to distinguish from the China Ranch fanglomerate because it was derived from the granite and gneiss clasts of the older unit. However, the morphology and structural features of the conglomerate unit are distinctive: (1) Younger fan deposits consistently slope toward the lake basin; whereas the China Ranch fanglomerate has generally steeper, more variable dips; (2) the younger unit has smaller clast sizes and large boulders (>1 m) are rare; (3) faulting is much more extensive in the China Ranch Beds; and (4) although the Quaternary conglomerate unit is interbedded with tuff A south of Tecopa, it does not contain the pumice cobble lenses that characterize the China Ranch Beds.

Tufa

The white flat-topped mounds along the western foot of the Resting Spring Range are thick accumulations of tufa. The tufa commonly consists of dense $\mathrm{CaCO}_{3}$ caprock, 2 to $4 \mathrm{~m}$ thick, over a layer of powdery white $\mathrm{CaCO}_{3}$. The powdery base, which commonly grades downward into the lacustrine mudstone unit, generally contains fossil ostracodes, thin-walled bone fragments, and reedlike plant stems. Caprock composition varies from cemented gravel to nearly pure fine-grained $\mathrm{CaCO}_{3}$ with stacked flattened pores or fenestrae. A few mounds have knobby surfaces of concentric travertine layers, although most of the mounds are capped by jagged solution-pitted blocks of tufa rubble.

The tufa forms two parallel discontinuous benches that are about $100 \mathrm{~m}$ apart laterally, several meters apart vertically, and which apparently follow the eastern shoreline of the ancient Lake Tecopa. Features of the shoreline such as beach gravels and sands are locally preserved in tufa, although the more typical mounds appear to have grown as wedges within mudstone beds near the stratigraphic levels of tuffs $\mathrm{A}$ and $\mathrm{B}$. The tufa mounds apparently formed while Lake Tecopa existed, because all mounds are associated with lake beds and tufa rubble forms clasts within alluvial deposits that postdate the lacustrine mudstone and conglomerate units. Accumulations of tufa probably formed by the precipitation of $\mathrm{CaCO}_{3}$ when carbonate-rich runoff or spring water entered the alkaline lake (Sheppard and Gude, 1968). No evidence of spring vents or carbonate-filled cracks was found in the lake beds near the mounds. Therefore, the alinement of tufa mounds is probably related to the ancient shoreline rather than more recent activity of springs along a fault zone.

\section{Age of Lake Tecopa}

Tephrachronology-Correlations of the Tecopa ash beds with isotopically dated volcanic sources are listed in table 1 , using $\mathrm{K}-\mathrm{Ar}$ ages that were calculated from the current decay constants and ${ }^{40} \mathrm{Ar} /{ }^{39} \mathrm{Ar}$ abundance (Steiger and Jager, 1977). Izett and others (1970) correlated the middle Tecopa ash bed, Tuff $\mathrm{B}$, with the Bishop Tuff in the Long Valley caldera of eastern California. Tuff B, also called the Bishop ash bed, is part of the tephra that was ejected from Long Valley when the Bishop Tuff was erupted, 0.73 m.y. ago (Dalrymple and others, 1965; Mankinen and Dalrymple, 1979). The correlation is

TABLE 1.-Correlation and dating of Lake Tecopa ash beds

\begin{tabular}{ccc}
\hline Ash beds of Lake Tecopa; nomenclature & Other correlative air-fall ashes (Preferred & Source of air-fall \\
of Sheppard and Gude (1968) and & name in parentheses) & ash
\end{tabular}
this report

Tuff $A$

Pearlette-like ash, Type $\mathrm{O}$ (Izett and others, 1970, 1972; Izett, 1981; SamaWojcicki and others, 1984)

(Ash of the Lava Creek Tuff)

Tuff B

Bishop ash (lzett and others, 1970; Sarna-Wojcicki and others, 1984)

(Ash of the Bishop Tuff)

Tuff C

Fission-track age, 1.6 Ma (C. E. Meyer, M. J. Woodward, and A. M. SarnaWojcicki, oral commun., Sept., 1981)
Pearlette-like ash, Type B (Izett, 1981; Sarna-Wojcicki and others, 1984); age $1.9 \pm 0.1 \mathrm{Ma}$ by fission-track dating (Naeser and others, 1973)

(Ash of the Huckleberry Ridge Tuff)
Lava Creek B ash of the Lava Creek Tuff (of the Yellowstone Group), Wyoming; age $0.62 \mathrm{Ma}$ by $\mathrm{K}-\mathrm{Ar}$ dating method (Christiansen and Blank, 1972; Izett and Wilcox, 1982)

Bishop Tuff, Long Valley caldera, California; age $0.73 \mathrm{Ma}$ by $\mathrm{K}$-Ar dating method (Dalrymple and others, 1965; Mankinen and Dalrymple, 1979)

Huckleberry Ridge Tuff (of the Yellowstone Group), Wyoming (Christiansen and Blank, 1972); age $2.02 \pm 0.08 \mathrm{Ma}$ by $\mathrm{K}$-Ar dating method (Reynolds, 1977; Love and Christiansen, 1980) 
founded on mineralogic similarities, shard morphology, microprobe analyses of major elements, spectrographic analysis of 11 trace elements in the glass shards, and paleomagnetism. Further substantiation of the correlation was provided by Sarna-Wojcicki and others (1984) in their study of tephra in the Western States. The method employs neutron-activation analysis to determine abundances of 20 minor and trace elements in volcanic glass. These abundances are combined with results of microprobe analysis for major elements in making regional correlation of air-fall tephra. An excellent match of elemental abundances was determined for tuff $B$ and basal pumice lapilli of the Bishop Tuff.

The chemistries of tuffs $A$ and $C$ match the elemental abundances of the family of tephra. that erupted from the Yellowstone caldera, $1,050 \mathrm{~km}$ northeast of the 'Tecopa basin. These widespread air-fall deposits, which were originally named the Pearlette ashes for exposures found in the Midwest, are now known to be the air-fall equivalents of welded tuffs in the Yellowstone caldera (Izett and others, $1970,1972)$. Tuff $A$, the youngest Tecopa ash, correlates with the Lava Creek B ash of the Lava Creek Tuff, dated by K-Ar methods at $0.62 \mathrm{Ma}$ (Izett, 1981; Christiansen and Blank, 1972; Izett and Wilcox, 1982). The original correlation, founded on petrographic similarities, stratigraphy, and major element chemistry, is further substantiated by neutron-activation analysis of trace and minor elements (Sarna-Wojcicki and others, 1984). The name "ash of the Lava Creek Tuff" which relates tuff $A$ to the source area, is now preferred over the original name, "Pearlette-like ash, type O", that was assigned by lzett and others (1970).

Sarna-Wojcicki and others (1984) and Izett (1981) tentatively correlate the lower Tecopa ash, tuff $\mathrm{C}$, with the older Pearlette ash bed of Meade County, Kansas. The ash bed in Kansas, referred to as "Pearlette-like ash, Type B", was correlated with the Huckleberry Ridge Tuff of the Yellowstone Group (Naeser and others, 1973). The age of the Huckleberry Ridge Tuff is $2.02 \pm 0.08 \mathrm{Ma}$, as measured by the K-Ar method (Reynolds, 1977; Love and Christiansen, 1980). Fission-track dating of the type-B Pearlette ash of Meade County, Kansas, yielded an age of $1.9 \pm 0.1 \mathrm{Ma}$ (Naeser and others, 1973). However, preliminary analysis of fresh tuff $\mathrm{C}$ from the Lake Tecopa beds gives a fission-track age of $1.6 \mathrm{Ma}$ (C. E. Meyer, M. J. Woodward, and A. M. Sarna-Wojcicki, oral commun., September, 1981).

Paleomagnetic Stratigraphy_Paleomagnetic work in the Lake Tecopa beds is consistent with the chronology that is established from the volcanic ashes. The paleomagnetic correlation method involves establishing the pattern of magnetozones, defined by the magnetic polarity of oriented specimens, for comparison with the geomagnetic polarity time scale (Mankinen and Dalrymple, 1979). Oriented specimens were collected from four stratigraphic sections, which collectively represent the lake beds from the base up to tuff $A$. Three oriented specimens, collected within a lateral distance of $50 \mathrm{~cm}$, were collected at stratigraphic horizons about $1 \mathrm{~m}$ apart. This sampling procedure was used at three of the sections. The remaining section was sampled more densely: four specimens per horizon at stratigraphic intervals of $15 \mathrm{~cm}$ (fig. 3). The polarity of each horizon was interpreted according to the method of Hillhouse and others (1977), and a generalized magnetostratigraphy, which combines data from all columns, was constructed (fig. 4).

The interval from tuff $A$ down to tuff $B$ (ash of the Bishop Tuff) is consistently of normal polarity. As shown in figure 3, a polarity transition is found approximately $50 \mathrm{~cm}$ below tuff $B$ (Hillhouse and Cox, 1976). This transition, which was confirmed by spot sampling at five localities around the basin, is undoubtedly the transition from the Matuyama Reversed Chron to the Brunhes Normal Chron; the transition has an estimated age of $0.73 \mathrm{Ma}$ (Mankinen and Dalrymple, 1979). The position of this transition just below the ash of the Bishop Tuff is consistent with the paleomagnetism of dated volcanic units in Long Valley and the Western States.

As shown in figure 4, two normally polarized magnetozones below tuff $B$ are tentatively correlated with the Jaramillo $(0.97-0.90 \mathrm{Ma})$ and Olduvai Normal Subchrons of the Matuyama Reversed Chron (1.87-1.67 $\mathrm{Ma}$ ). Finally, at the bottom of the stratigraphic section, tuff $C$ is within a reversed magnetozone that is consistent with the older part of the Matuyama Reversed Chron (2.48$1.87 \mathrm{Ma}$ ). This correlation is in agreement with $\mathrm{K}$-Ar dating (2.02 Ma) of the Huckleberry Ridge Tuff, which is the presumed source of tuff $\mathrm{C}$. The fission track age (1.6 Ma) determined from Tuff $\mathrm{C}$ is not consistent with this interpretation of the magnetic stratigraphy. Correlations are made with considerable uncertainty in the lower part of the Tecopa lake beds for two reasons: (1) despite cleaning treatments, postdepositional remagnetization of normal polarity persists throughout the lower horizons at Lake Tecopa, and (2) in the polarity time scale, the placement and duration of normal polarity subchrons have not been fully resolved for the lower part of the Matuyama.

Depositional rates-On the basis of time lines provided by the ash beds, rates of deposition were approximately $0.06 \mathrm{~m} / 1,000$ yr between tuffs $A$ and $B$ and $0.015 \mathrm{~m} / 1,000$ yr between tuffs $B$ and $C$. By extrapolating these rates to cover the beds of the lacustrine mudstone unit that are above tuff $\mathrm{A}$ and below tuff $\mathrm{C}$, a cumulative age of 3.0-0.5 Ma was obtained for the lake beds. These limits should be considered rough estimates because the rates of deposition vary by a factor of four within the. section. In addition, the maximum age of the lake is very uncertain because the base of the deposits is not exposed in the central basin.

According to the geologic time table of van Eysinga (1978), the lake beds are late Pliocene and early Pleistocene in age. The Pliocene-Pleistocene boundary (beginning of the Olduvai Normal Subchron) is a few meters above tuff $\mathrm{C}$. The younger age limit of the lake beds is slightly younger than the early-late Pleistocene boundary (Brunhes-Matuyama transition).

Paleontology_Sheppard and Gude (1968) described localities of fossils found prior to 1966 in the deposits of Lake Tecopa. The upper part of the beds contains rare horse, camel, mammoth, and muskrat fossils, too fragmentary for age-diagnostic identification. Sheppard and Gude also reported several localities of ostracodes and 


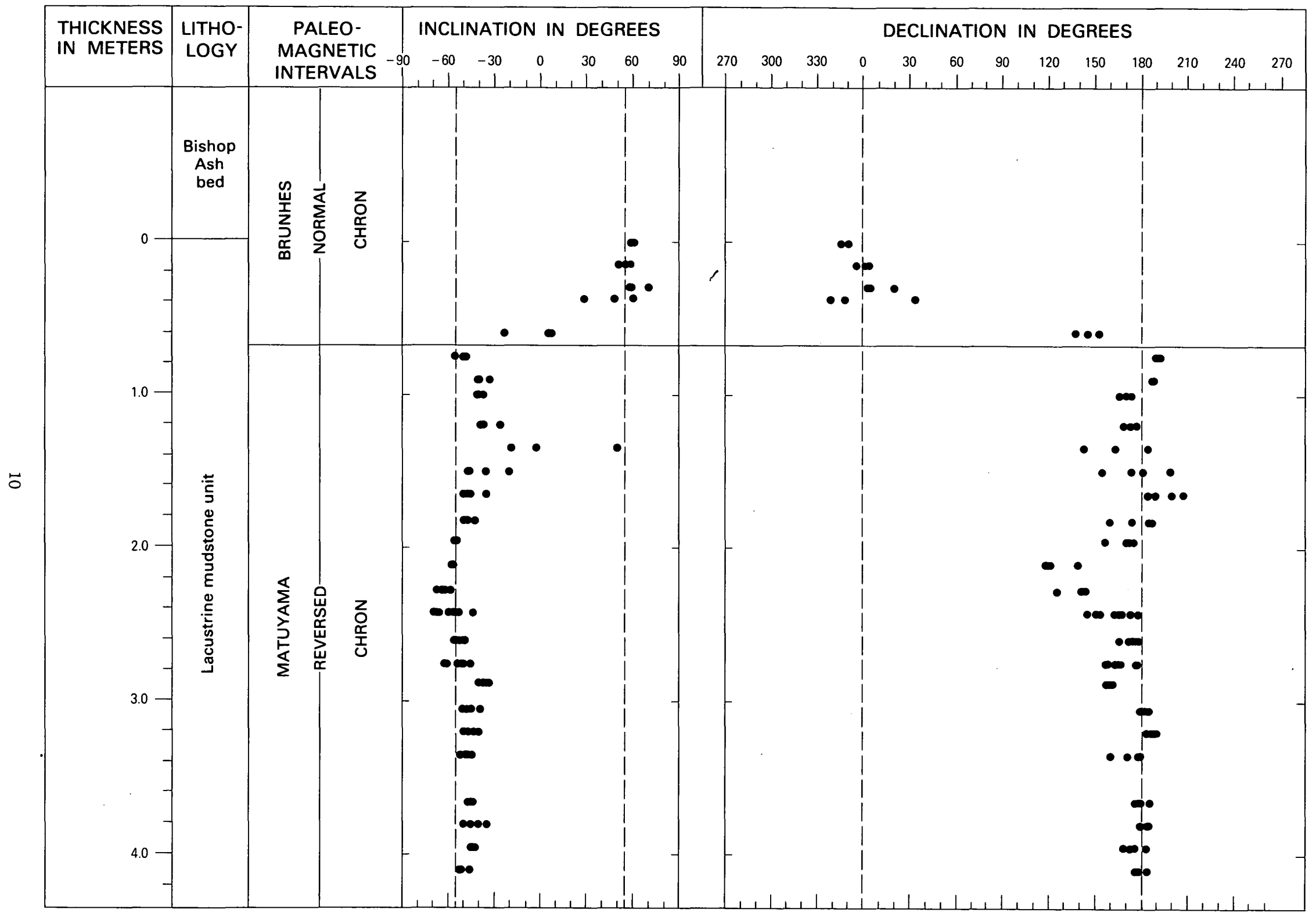

FIGURE 3.-Paleomagnetic data used in determining transition from the Matuyama Reversed Chron to the Brunhes Normal Chron (0.73 Ma). Transition is present $50-75 \mathrm{~cm}$ below the ash of the Bishop Tuff. Sample locality is $2 \mathrm{~km}$ east of Shoshone. 


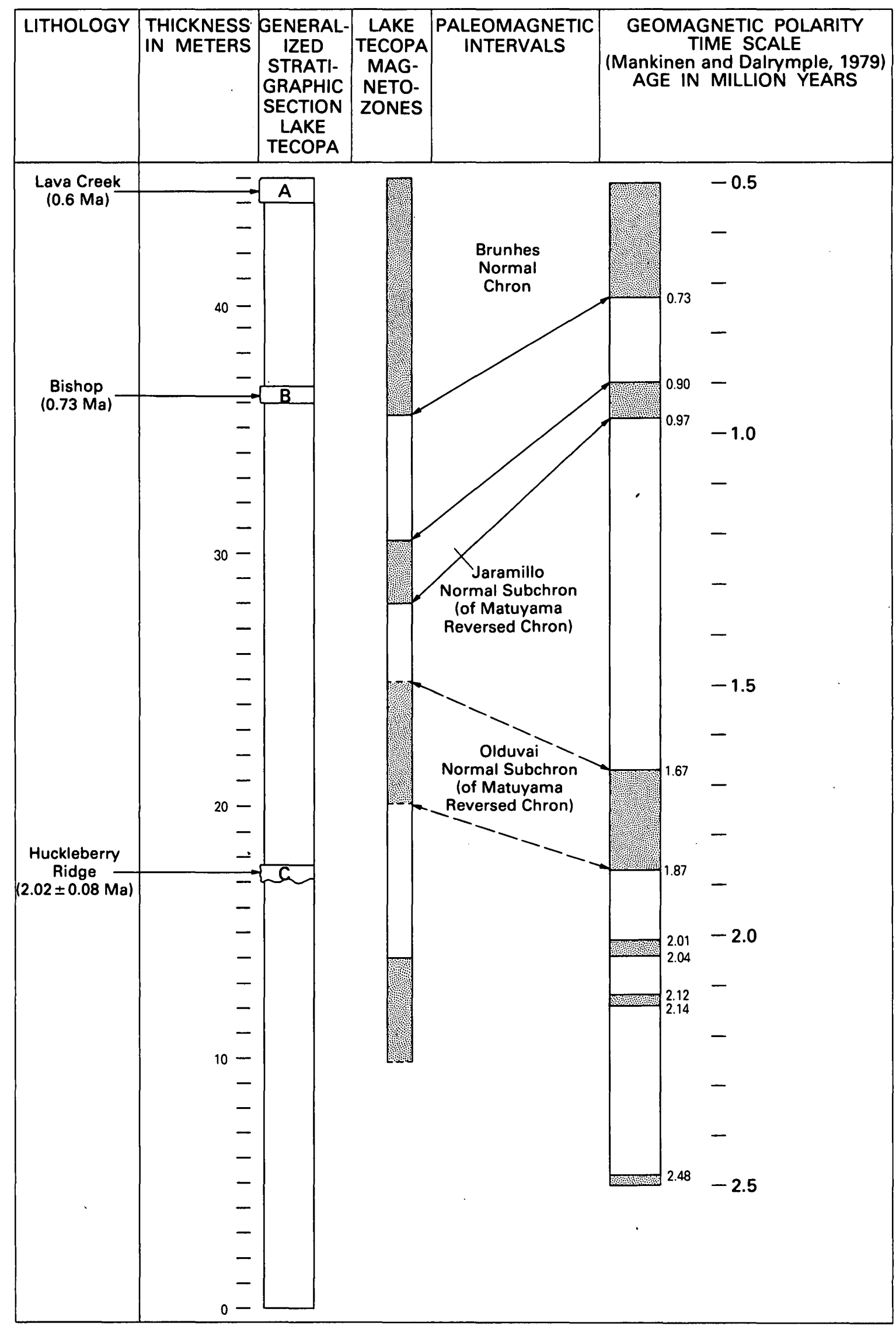

FIGURE 4.-Correlation of Lake Tecopa magnetozones with geomagnetic polarity time scale of Mankinen and Dalrymple (1979). Stippled areas denote normal polarity; white areas denote reversed polarity. 
diatoms (42 species and varieties) from the upper lake beds. Three of the diatom species indicated a middle to late Pleistocene age, and the ostracodes did not contradict a Pleistocene age.

Since 1971, several collections of vertebrate fossils have been taken from the vicinity of Tecopa (table 2). These collections are held by the Los Angeles County Museum of Natural History (D. P. Whistler, written commun., 1983). Because the Tecopa fauna has not been studied in detail, the identifications are preliminary. Slightly below the level of tuff $C$ (localities $4-6$, table 2) the larger vertebrate fauna is dominated by camels, including one taxa that is new at the generic level. The same area has yielded abundant micromammal fossils, which are housed in the Earth Sciences Department collections at the University of California, Riverside. Although the collections are not formally described, they include a number of microtine rodents related to pack rats that are recognized as valuable biostratigraphic indicators (Repenning, 1980; May and Repenning, 1982). Evidence of Mammuthus (locality 1, table 2) from the upper part of the section is consistent with a late Pleistocene age. QUATERNARY OLDER ALLUVIUM

Older alluvium (unit $\mathrm{Qa}_{2}$ ) consists of remnants of alluvial fans which now form prominent mesas and raised areas capped by desert pavement. These remnants generally stand 1 to $10 \mathrm{~m}$ above the active washes and are no longer receiving sediment. A good example is the abandoned fan in Greenwater Valley.
Thickness of the older alluvium ranges from a thin gravelly veneer $(30 \mathrm{~cm})$ in the central basin to thick wedges $(100 \mathrm{~m})$ of bouldery conglomerate at the range fronts. Clasts consist of subangular dolomite, quartzite, and silicic volcanic rocks from the surrounding ranges, and tufa and zeolitic tuff from the lake beds. The gravelly deposits are crudely interbedded with sand, are poorly indurated, and lack substantial deposits of pedogenic caliche. In the central basin, the older alluvium was deposited as a true pediment on the eroded surface of the lake beds, the eroded surface having several meters of relief.

The morphology of the older alluvium is planar in the central basin, and gives way to gently concave slopes that rise about $100 \mathrm{~m}$ from the basin floor to the range fronts. The unit forms coalescing, conical fans with steep slopes at the foot of the bedrock ranges. The older alluvium is typically deeply dissected by the modern washes, so that the unit forms fingerlike mesas near the margin of the lake beds.

A distinguishing feature of the older alluvium is its surface of desert pavement and advanced development of soil. The desert pavement consists of planar surfaces of densely packed pebbles and cobbles, predominantly 2-5 $\mathrm{cm}$ in diameter. Scattered larger cobbles and boulders as much as $1 \mathrm{~m}$ in diameter commonly protrude above the close-packed surface. Clasts were derived from the underlying fan deposits; although atop the tufa benches, the pavement consists of flat $\mathrm{CaCO}_{3}$ plates. Color of the pavement surface ranges from dark red brown to black, depending on the degree of varnish development.

TABLE 2.- Vertebrate fossil collections

[Locations are shown on map. List compiled by D. P. Whistler, Los Angeles County Museum of Natural History (LACM)]

1. Locality LACM 1209 (sec. 35, T. 21 N., R. 6 E.)

Mammuthus (mammoth)

Equidae, small species (horse)

cf. Hemiauchenia (llama)

2. Locality LACM 1210 (sec. 7, T. 20 N., R. 7 E.)

Equidae, large species

cf. Camelops (camel)

cf. Titanotylopus (large camel)

cf. Hemiauchenia

3. Locality LACM 3772, 6805 (Approximate location: sec. 33 and 34, T. 21 N., R. 7 E.)

Mastodontidae (mastodon)

Equidae, small species

cf. Titanotylopus

cf. Hemiauchenia

Antilocapridae, large species (antelope)

4. Locality LACM 7104 and:

5. Locality LACM 7106 (sec. 27, T. 21 N., R. 7 E.)

cf. Camelops

cf. Titanotylopus

cf. Hemiauchenia

6. Locality LACM $7108,7109,7111,7112,7113,7132$ (sec. 23, T. 21 N., R. 7 E.)

Phoenicopteridae (flamingo)

Mastodontidae

Equidae, small species

Equidae, large species

cf. Camelops

cf. Titanotylopus

cf. Hemiauchenia

Miolabinae, new genus and species (camel) 
Quartzite and dolomite clasts acquire little or no varnish, while volcanic clasts have the darkest accumulations. The planar surface is broken by occasional risers as much as 10 $\mathrm{cm}$ high.

Directly beneath the armor of pebbles is a layer almost entirely composed of brown silt (A-horizon), 10-30 cm. thick, which contains spherical cavities $1-3 \mathrm{~mm}$ in diameter. Origin of this silt bed has been explained as the product of desert soil-forming processes, or alternatively, as a widespread loess deposit. For example, Denny (1965) attributed the silt to a mechanical weathering process driven by wetting and drying, which causes larger rock fragments to be lifted to the surface. Hoover and others (1981) favored an aeolian origin for the silt, mainly because the silt has a uniform composition despite the lithology of underlying material.

The vesicular silt is generally underlain by a buff or reddish-brown pebbly $\mathrm{B}$-horizon. The layer, which rarely exceeds $50 \mathrm{~cm}$ in thickness, is enriched in clay, iron oxide, and calcium carbonate. Pebbles near the base of this zone commonly have a thin $(1-3 \mathrm{~mm})$ undercoating of $\mathrm{CaCO}_{3}$ (stage I of Gile and others, 1966), but the soil lacks dense $\mathrm{CaCO}_{3}$ horizons. Although the pavement and soil horizons are commonly developed on the older alluvium, they locally cap remnants of the Quaternary conglomerate unit of lakebed age, especially near the range fronts. Therefore, the surface of the Quaternary conglomerate can be similar to the surface of the older alluvium. Such areas have been mapped as the Quaternary conglomerate, because the soil forms only a thin veneer.

In an effort to date the Quaternary older alliuvium, samples for the uranium-trend method (Rosholt, 1978) were collected from a gravel pit $2.5 \mathrm{~km}$ east of Shoshone. Samples taken from the B-horizon of the soil yielded an age of $160,000 \pm 18,000$ yr B.P. (J. N. Rosholt, oral commun., October 1981).

\section{HOLOCENE ALLUVIUM}

The younger alluvial deposits (unit $\mathrm{Qa}_{1}$ ) consist of unconsolidated sand, silt, and conglomerate in active and recently abandoned stream channels. The main channel is the Amargosa River bed which is a braided complex of washes and gravel bars with microrelief of $0.3-2 \mathrm{~m}$. Tributary washes that originate on the range fronts are commonly deeply incised (as much as $15 \mathrm{~m}$ ) into the older fan deposits. Near the ranges, the washes contain a mixture of sand, subangular cobbles, and boulders of dolomite, quartzite, and basalt; whereas, the Amargosa River bed predominantly consists of sand and subrounded cobbles. Pavements and varnish are poorly developed and soils are absent in the recently abandoned washes, which are presumed to be of Holocene age. In the central part of the Lake Tecopa beds, the recent deposits consist of loose silt and clay which form a small playa. When dry, the playa surface develops a white efflorescence of halite and gypsum (Starkey and Blackmon, 1979). The only Holocene aeolian deposits of the basin are a few dunes and southwest-trending streaks of sand near Tecopa Hot Springs.

The recent features suggest a regime in which erosion has dominated over deposition within the Tecopa basin. Deeply incised washes are carrying coarse debris from the ranges beyond the older alluvial fans. Downcutting has been rapid in Amargosa canyon as indicated by Holocene terraces now standing 3-4 $\mathrm{m}$ above the active stream bed. Major areas of recent deposition are the Amargosa River bed, the playa, and areas of sheetwash on the older fan deposits. These places of deposition appear to be temporary storage areas for material that will eventually be swept through Amargosa canyon by floodwaters.

\section{LATE TERTIARY AND QUATERNARY STRUCTURAL FEATURES}

A major episode of faulting and folding occurred after deposition of the China Ranch Beds and prior to deposition of the beds of Lake Tecopa. High-angle faults with vertical offsets as much as $100 \mathrm{~m}$ are common in the China Ranch fanglomerates in Amargosa canyon. These faults do not cut the Quaternary conglomerate unit or the Lake Tecopa beds. The China Ranch Beds are extensively folded as well as being faulted, although folding is more prominent in the lacustrine mudstone unit than in the fanglomerate. The presence of megabreccia and huge slide blocks within the China Ranch fanglomerates suggests that deformation was contemporaneous or followed soon after deposition of the beds. This time interval, probably occurring during the Pliocene, was also marked by volcanic activity which supplied pumice to the nearby drainages.

Only minor faulting occurred in the Tecopa basin after the major Pliocene episode. High-angle faults having vertical displacements of as much as $3 \mathrm{~m}$ were recognized in a few areas of the Lake Tecopa beds, most commonly in the low hills northeast of Tecopa Hot Springs. Deformation, probably due to differential compaction of the lake beds, is localized and minor. For example, a small dome with dips as much as $8^{\circ}$ is exposed beside California Highway 127, $3 \mathrm{~km}$ south of Shoshone. Disturbed beds that contain tuff B are exposed at the southwest end of Greenwater Valley, but these features were probably caused by slumping of channel walls during early erosion of the Tecopa beds. Careful examination of aerial photographs and field checks failed to detect any faults within the Holocene or older Quaternary alluvial deposits. Although the linear course of the Amargosa River suggests that it follows a fault, no evidence of such a fault was found in the flanking terraces. Apparently, the faults which caused uplift of the Dublin Hills and Resting Spring Range ceased activity prior to deposition of the Lake Tecopa beds.

The base of tuff $\mathrm{B}$ provides a datum for detecting large-scale tilt due to regional deformation or faulting within the basin. Although elevation of the tuff ranges from 430 to $540 \mathrm{~m}$ above sea level, almost all of the variation is attributable to a gentle dip $\left(1^{\circ}\right)$ of the beds toward the center of the basin. Compaction and the original lake bottom topography can account for the gentle basinward dip. Near the lake margin, the elevation of tuff $B$ ranges from $495 \mathrm{~m}$ at Shoshone to $468 \mathrm{~m}$ at the northern tip of the Sperry Hills. The difference in elevation allows a maximum south and downward tilt of $0.1^{\circ}$. The maximum allowable tilt in the east-west direction is $0.2^{\circ}$ downward to the west. Therefore, the region has not been tilted appreciably since about 500,000 years ago. 


\section{CONCLUSIONS}

About three million years ago, the Tecopa basin was an alluviated depression, closed at the south end by thick fanglomerates of the China Ranch Beds. These beds were perhaps uplifted by faulting to form a dam for Lake Tecopa. At this time, climatic conditions favored the formation of a moderately deep lake rather than a playa, as indicated by geochemical studies and depositional features of the lake beds (Sheppard and Gude, 1968; Starkey and Blackmon, 1979). The presence of saline minerals, magadiite, and certain zeolite minerals indicate that Lake Tecopa, at least in its later stages, was highly alkaline and saline due to evaporation. Therefore, the lake did not have a permanent outlet during its long history.

The existence of Lake Tecopa for over 2 million years raises the question of whether the Amargosa region was considerably less arid during the early Pleistocene as compared to today. One way to examine this question is to determine whether current amounts of spring discharge and runoff would support a lake in the Tecopa basin if an outlet did not exist. The ratio of drainage basin area to the area of Lake Tecopa is approximately 42:1 (Snyder and others, 1964). Observations from Nevada indicate that potential annual evaporation exceeds precipitation by a factor of roughly 5 to 25 times (Winograd and Thordarson, 1975). The factor may exceed this range in the Tecopa basin, because the average elevation $(460 \mathrm{~m})$ is relatively low. If we assume that for the entire drainage area less than 10 percent of the total precipitation would reach the lake as runoff, then an evaporation/precipitation factor of 4.2 or greater would preclude maintenance of a lake in the Tecopa basin. Additional water from springs, such as the group at Ash Meadows which annually supply about 17,000 acre-ft (22-million $\mathrm{m}^{3}$ ) (Winograd and Thordarson, $1975)$, could bring roughly 3 in. $(8 \mathrm{~cm})$ of water to the lake yearly, and offset only 5 percent of the potential annual evaporation. Therefore, the current water supply is inadequate to balance evaporation and thereby sustain a perennial lake in the Tecopa basin.

Considering the inadequacy of current water sources to sustain a lake in the basin, precipitation or spring discharge must have been substantially greater, and evaporation lower, during the existence of Lake Tecopa 3.0-0.5 m.y. ago. Inflow and evaporation maintained a balance while the basin steadily filled with sediment. Sometime after deposition of the ash of the Lava Creek Tuff, 0.6 m.y. ago, the barrier at the south end of the lake was breached, probably by overflow. The general lack of tectonic activity during this period rules out breaching due to tilting or faulting. The lake drained rapidly as the Amargosa canyon developed, creating a link between the upper Amargosa basins and Death Valley. Following the creation of this link, subsidence of Death Valley due to faulting could affect rates of erosion in the Tecopa basin.

More than about 160,000 years ago, the eroded surface of the Lake Tecopa beds was partly buried by alluvial fans which extended from the nearby ranges. Although the change from an erosional regime to one of deposition remains unexplained, a climatic change is favored, because the alluviation appears to have occurred throughout the Amargosa region $80,000-430,000$ years ago (Hoover and others, 1981).

As the supply of material to the alluvial fans waned, and as stream channels deepened, parts of the fans were abandoned as sites of deposition, and soils and pavements began to form on surfaces of the fans. The Tecopa basin bears no evidence of a pluvial lake of Lahontan age, probably because the basin has not been closed since the Amargosa River canyon formed. In the Holocene, the rate of erosion apparently increased, because the deepening of stream channels dominated the building of new fans.

\section{ACKNOWLEDGMENTS}

1 have benefitted from geologic discussions with Wilfred J. Carr, David L. Hoover, and W. C. Swadley of the U.S. Geological Survey, and Richard L. Hay of the University of Illinois. Appreciation is expressed to Andrei M. Sarna-Wojcicki (U.S. Geological Survey) for assistance with the geochronology of Lake Tecopa, to Brigitte Smith of the University of Paris for help during the paleomagnetic study, and to D. P. Whistler (Los Angeles County Museum of Natural History) for information concerning the Tecopa vertebrate fossils.

\section{REFERENCES CITED}

Blackwelder, Eliot, 1936, Pleistocene Lake Tecopa [abs.]: Geological Society of America Proceedings for 1935, p. 333.

Chesterman, C. W., 1973, Geology of the northeast quarter of Shoshone quadrangle, Inyo County, California: California Division of Mines and Geology Map Sheet 18, scale 1:24,000.

Christiansen, R. L., and Blank, H. R., Jr., 1972, Volcanic stratigraphy of the Quaternary rhyolite plateau in Yellowstone National Park: U.S. Geological Survey Professional Paper 729-B, p. B1-B18.

Dalrymple, G. B., Cox, A., and Doell, R. R., 1965, Potassium-argon age and paleomagnetism of the Bishop Tuff: Geological Society of America Bulletin, v. 76, p. $665-675$.

Denny, C. S., 1965, Alluvial fans in the Death Valley region, California and Nevada: U.S. Geological Survey Professional Paper 466, $62 \mathrm{p}$.

Denny, C. S., and Drewes, Harald, 1965, Geology of the Ash Meadows quadrangle, Nevada-California: U.S. Geological Survey Bulletin 1181-L, p. L1-L56.

Drewes, Harald, 1963, Geology of the Funeral Peak quadrangle, California, on the east flank of Death Valley: U.S. Geological Survey Professional Paper 413, $78 \mathrm{p}$.

Fleck, R. J., 1970, Age and tectonic significance of volcanic rocks, Death Valley area, California: Geological Society of America Bulletin, v. 81, p. 2807-2816.

Gile, L. H., Peterson, F. F., and Grossman, R. B., 1966, Morphological and genetic sequences of carbonate accumulation in desert soils: Soil Science, v. 101, p. 347-360.

Haefner, Richard, 1976, Geology of the Shoshone Volcanics, Death Valley region, eastern California: California Division of Mines and Geology, Special Report 106, p. 67-72.

Hazzard, J. C., 1937, Paleozoic sections in the Nopah and Resting Spring Mountains, Inyo County, California: 
California Journal Mines and Geology, v. 33, no. 4, p. 273-339.

Hillhouse, Jack, and Cox, Allan, 1976, Brunhes-Matuyama polarity transition: Earth and Planetary Science Letters, v. 29, p. 51-64.

Hillhouse, J. W., Ndombi, J. W. M., Cox, A., and Brock, A., 1977, Additional results on paleomagnetic stratigraphy of the Koobi Fora Formation east of Lake Turkana (Lake Rudolf), Kenya: Nature, v. 265, p. $411-415$.

Hoover, D. L., Swadley, W. C., and Gordon, A. J., 1981, Correlation characteristics of surficial deposits with a description of surficial stratigraphy in the Nevada Test Site region: U.S. Geological Survey Open-File Report $81-512,30 \mathrm{p}$.

Izett, G. A., 1981, Stratigraphic succession, isotopic ages, partial chemical analyses, and sources of certain silicic volcanic ash beds $(4.0$ to $0.1 \mathrm{~m} . \mathrm{y}$.) of the Western United States: U.S. Geological Survey Open-File Report 81-763, 2 sheets.

Izett, G. A., and Wilcox, R. E., 1982, Map showing localities and inferred distributions of the Huckleberry Ridge, Mesa Falls, and Lava Creek ash beds (Peariette family ash beds) of Pliocene and Pleistocene age in the western United States and southern Canada: U.S. Geological Survey Miscellaneous Geologic Investigations Series map I-1325, 1:4,000,000.

Izett, G. A., Wilcox, R. E., and Borchardt, G. A., 1972, Correlation of a volcanic ash bed in Pleistocene deposits near Mount Blanco, Texas, with the Guaje pumice bed of the Jemez Mountains, New Mexico: Quaternary Research, v. 2, p. 554-578.

Izett, G. A., Wilcox, R. E., Powers, H. A., and Desborough, G. A., 1970, The Bishop ash bed, a Pleistocene marker bed in the western U.S.: Quaternary Research, v. 1, p. 121-132.

Love, J. D., and Christiansen, A. C., 1980, Preliminary correlation of stratigraphic units used on $1^{\circ} \times 2^{\circ}$ geologic quadrangle maps of Wyoming: Wyoming Geological Association Guidebook, Annual Field Conference, v. 31, p. 279-282.

Mankinen, E. A., and Dalrymple, G. B., 1979, Revised geomagnetic polarity time scale for the interval 0-5 m.y. B.P.: Journal of Geophysical Research, v. 84, p. 615-626.

Mason, J. F., 1948, Geology of the Tecopa area, southeastern California: Geological Society of America Bulletin, v. 59, no. 4, p. 333-352.

May, S. R., and Repenning, C. A., 1982, New evidence for the age of the Old Woman Sandstone, Mojave Desert, California: in Cooper, J. D., compiler, Guidebook for the Geological Society of America Cordilleran Section Meeting, Anaheim, California, p. 93-96.

McAllister, J. F., 1973, Geologic map and sections of the Amargosa Valley borate area-southeast continuation of the Furnace Creek area-Inyo County, California: U.S. Geological Survey Miscellaneous Investigations Series Map I-782, scale 1:24,000.

McElhinny, M. W., 1973, Paleomagnetism and plate tectonics: Cambridge University Press, New York, 358 p.

Naeser, C. W., Izett, G. A., and Wilcox, R. E., 1973, Zircon fission-track ages of Pearlette family ash beds in Meade County, Kansas: Geology, v. 4, p. 187-189.

Noble, L. F., and Wright, L. A., 1954, Geology of the central and southern Death Valley region, California, in Jahns, R. H., editor, Geology of southern California: California Division of Mines, Bulletin 170, Chapter 2, p. 143-160.

Repenning, C. A., 1980, Faunal exchanges between Siberia and North America: Canadian Journal of Anthropology, v. 1, p. 37-44.

Reynolds, R. L., 1977, Comparison of the TRM of the Yellowstone Group and the DRM of some Pearlette ash beds: Journal of Geophysical Research, v. 84, p. $4525-4536$

Rosholt, J. N., 1978, Uranium-trend dating of alluvial deposits; in R. E. Zartman, ed., Fourth International Conference, Geochronology, Cosmochronology, and Isotope Geology: U.S. Geological Survey Open-File Report 78-701, p. 360-362.

Sarna-Wojcicki, A. M., Bowman, H. R., Meyer, C. E., Russell, P. C., Woodward, M. J., McCoy, Gail, Rowe, J. J., Jr., Baedecker, P. A., Asaro, Frank, and Michael, Helen, 1984, Chemical analyses, correlations, and ages of upper Pliocene and Pleistocene ash layers of east-central and southern California: U.S. Geological Survey Professional Paper 1293, $40 \mathrm{p}$.

Sheppard, R. A., and Gude, A. J., 3d, 1968, Distribution and genesis of authigenic silicate minerals in tuffs of Pleistocene Lake Tecopa, Inyo County, California: U.S. Geological Survey Professional Paper 597, 38 p.

Snyder, C. T., Hardman, George, and Zdenek, F. F., 1964, Pleistocene lakes in the Great Basin: U.S. Geological Survey Miscellaneous Geologic Investigations Map I-416, scale 1:1,000,000.

Starkey, H. C., and Blackmon, P. D., 1979, Clay mineralogy of Pleistocene Lake Tecopa, Inyo County, California: U.S. Geological Survey Professional Paper $1061,34 \mathrm{p}$.

Steiger, R. H., and Jager, E., 1977, Subcommission on Geochronology: Convention on the use of decay constants in geo- and cosmochronology: Earth and Planetary Science Letters, v. 36, p. 359-362.

Troxel, B. W., and Heydari, Ezat, 1982, Basin and range geology in a roadcut, in Geology of Selected Areas in the San Bernardino Mountains, western Mojave Desert, and Southern Great Basin, California, Cooper, J. D., Troxel, B. W., and Wright, L. A., eds., Geological Society of America, Cordilleran Section, guidebook, p. 91-96.

Troxel, B. W., and Wright, L. A., eds., 1976, Geologic features, Death Valley, California: California Division of Mines and Geology Special Report 106, 72 p.

van Eysinga, F. W. B., 1978, Geological time table, 3rd Edition: Elsevier Scientific Publishing Company, Amsterdam, The Netherlands, 1 Sheet. 
Winograd, I. J., and Thordarson, William, 1975, Hydrogeologic and hydrochemical framework, southcentral Great Basin, Nevada-California; with special reference to the Nevada Test Site: U.S. Geological Survey Professional Paper 712-C, p. C1-C126.
Wright, L. A., 1974, Geology of the southeast quarter of the Tecopa quadrangle, San Bernardino and Inyo Counties, California: California Division of Mines and Geology Map Sheet 20, scale 1:24,000. 